\title{
Is thermal stability a factor that influences environmental heterogeneity and phytoplankton distribution in tropical lakes?
}

\author{
A estabilidade térmica é um fator que influencia a heterogeneidade ambiental e a
} distribuição do fitoplâncton em lagos tropicais?

\author{
Luciana Gomes Barbosa ${ }^{1 *}$, Francisco Antônio Rodrigues Barbosa ${ }^{2}$ \\ and Carlos Eduardo de Mattos Bicudo ${ }^{3}$
}

\begin{abstract}
${ }^{1}$ Laboratório de Limnologia, Departamento de Fitotecnia e Ciências Ambientais, Universidade Federal da Paraíba - UFPB, Campus II, Rodovia BR 079, Km 12, CEP 58397-000, Areia, PB, Brasil

${ }^{2}$ Laboratório de Limnologia, Ecotoxicologia e Ecologia Aquática - LIMNEA, Instituto de Ciências Biológicas, Universidade Federal de Minas Gerais - UFMG, Av. Presidente Antônio Carlos, 6627, Pampulha, CEP 31270-901, Belo Horizonte, MG, Brasil

${ }^{3}$ Núcleo de Pesquisas em Ecologia, Instituto de Botânica, Av. Miguel Stéfano, 3687, Água Funda, CP 68041, CEP 04045-972, São Paulo, SP, Brasil

*e-mail: lucianabarbosa@cca.ufpb.br
\end{abstract}

Cite as: Barbosa, L.G., Barbosa, F.A.R. and Bicudo, C.E.M. Is thermal stability a factor that influences environmental heterogeneity and phytoplankton distribution in tropical lakes? Acta Limnologica Brasiliensia, 2018, vol. 30, e207.

Abstract: Aim: To evaluate the effects of environmental heterogeneity promoted by thermal stratification on the distribution of limnologic variables and phytoplankton functional groups (FGs) in two natural lakes. Methods: Monthly measurements were performed over a five-year period in the vertical profile of a warm monomitic shallow lake (Lago Carioca) and in a deep and meromictic (Lake Dom Helvécio). Results: The vertical zonation generated by the high thermal stability during the stratification period promoted an increase in the spatial heterogeneity and, consequently, in the richness of functional groups of the two lakes. In the epilimnion, the dominance of small chlorophytes and desmids (NA, A and X1, $\leq 20 \mu \mathrm{m}$ ) and larger dinophyceans (Lo, $\geq 20 \mu \mathrm{m}$ ) were associated with high turbulence and light availability and soluble phosphorus limitation. In the metalimnion, the presence of filamentous cyanobacteria (R) and colonial chlorophyceans (F) of larger size $(\geq 20 \mu \mathrm{m})$ were associated with stable habitats with high concentrations of N-NH4 and P-PO4-3 and light limiting conditions. Comparatively, Lake Dom Helvécio presented a higher richness of FGs in the meta-hipolimnetic layers $(\mathrm{SN}, \mathrm{P})$ as well as a higher number of species per functional group. Seasonal changes in the climatic conditions (e.g. the decrease in air temperature with the consequent heat loss) caused the break of the water column stability, which promoted the redistribution of the dissolved nutrient forms and the increase of light limitation in the two lakes during the mixing period. Therefore, there was a drastic reduction in the richness and population biomass of FGs $(\leq 80 \%)$. Conclusions: Thermal stability and atelomixis were the main driving forces of vertical heterogeneity during the stratification, favoring the coexistence of FGs and, consequently, their increase in richness and biomass.

Keywords: atelomixis; environmental changes; functional groups; thermal stratification.

Resumo: Objetivo: Avaliar os efeitos da heterogeneidade ambiental promovida pela estratificação térmica sobre a distribuição de variáveis limnológicas e de grupos funcionais fitoplanctônicos (GF's) em dois lagos naturais. Métodos: Foram realizadas medidas mensais no perfil vertical de um lago 
raso monomítico quente (Lago Carioca) e em um profundo e meromítico (Lago Dom Helvécio), ao longo de cinco anos. Resultados: A zonaçáo vertical evidente gerada pela elevada estabilidade térmica durante o período de estratificaçáo favoreceram o aumento da heterogeneidade espacial e, consequentemente, da riqueza de grupos funcionais nos dois lagos. No epilímnio, ocorreu dominância de clorofíceas e desmídias de pequeno tamanho (NA, A e X1, $\leq 20 \mu \mathrm{m}$ ) e dinofíceas de maior porte (Lo, $\geq 20 \mu \mathrm{m})$, associadas a alta turbulência, disponibilidade de luz e limitação por fósforo solúvel. No metalímnio, foram observadas cianobactérias filamentosas (R) e clorofíceas coloniais (F) de maior tamanho $(\geq 20 \mu \mathrm{m})$, associadas a hábitats estáveis com elevadas concentraçóes de N-NH4 e P-PO4-3 e condiçóes limitantes de luz. Comparativamente, o lago Dom Helvécio registrou maior riqueza de GF's nas camadas meta-hipolimnéticas (SN, P) bem como maior de número de espécies acomodadas por grupo. Sazonalmente, mudanças nas condiçóes climáticas (ex. redução da temperatura do ar provocando perda de calor) causaram a quebra da estabilidade da coluna d'água, o que promoveu a redistribuição das formas dissolvidas de nutrientes e o aumento da limitação por luz nos dois lagos durante o período de mistura. Como consequência, foi identificada uma drástica redução de riqueza de GF's e da biomassa das populaçôes $(\leq 80 \%)$. Conclusóes: A estabilidade térmica e atelomixia foram funçôes de força fundamentais na geração de heterogeneidade vertical durante a estratificação, favorecendo a coexistência e, consequentemente, o aumento da riqueza e biomassa de GF's.

Palavras-chave: atelomixia; mudanças ambientais; grupos funcionais; estratificação térmica.

\section{Introduction}

Phytoplankton periodicity has been associated with seasonal stratification and turbulence cycles for a long time (Margalef, 1978). In lakes, water physical factors control the mechanisms of adjustment and the strategies of phytoplankton for adaptation to environmental changes (Margalef, 1978; Estrada \& Berdalet, 1997; Moreno-Ostos et al., 2006). Aquatic ecosystems have a complex spatial structure, being the phytoplankton patchiness physically controlled by light conditions and turbulence mixing (Moreno-Ostos et al., 2006).

Studies based on growth simulations indicated that phytoplankton responses are depending on the position of the layer hosting algal cells, the depth of the water column, the light availability and the shape and size of the water body (Rigosi \& Rueda, 2012). Changes in the phytoplankton dynamics in stratified lakes can be explained by the synergy between turbulence and the light conditions underwater (Moreno-Ostos et al., 2006), since light limitation strongly affects the succession and regulation of the plankton (Zohary et al., 2010).

Lewis Junior (1973) described the complete atelomixis as the mixing of the water column where a permanent thermocline can be established during summer in tropical monomitic lakes. Atelomixis has been frequently reported affecting phytoplankton in tropical lakes, however, since the thermocline is developed during the summer and contributes to epilimnetic mixing, it has been considered as a partial atelomixis (Barbosa \& Pádisak, 2002). Partial atelomixis possibly drives the selection of algal groups, favoring the maintenance of desmids (Barbosa \& Padisák, 2002; Padisák et al., 2009; Tavera \&
Martinez-Almeida, 2005) and the suspension of diatoms throughout the layer (Lopes et al., 2005).

The characteristics of the phytoplankton in lakes are selected according to the spatial complexity and temporal changes in environmental factors. MacArthur \& MacArthur (1961) considered that environments that are more heterogeneous turn resources more available and increase the number of niches, and consequently, support higher species diversity than less heterogeneous environments. Hutchinson (1961) stated that a large number of species might be able to coexist in a relatively isotropic environment. Therefore, environmental heterogeneity enhanced by vertical gradients of temperature can have great influence in the vertical distribution of phytoplankton (Mellard et al., 2011).

Currently, 40 polyphyletic functional groups of phytoplankton are recognized (Padisák et al., 2009) according to the classical and widely used system of phytoplankton classification, which is highly predictive for tropical and subtropical water bodies (Salmaso et al., 2015). In this paper, we characterized the phytoplankton functional groups and analyzed their responses to seasonal variation in the thermal structure of two lakes in the state of Minas Gerais, Brazil. In addition, we sought to answer the following question: Does the apparent increase in heterogeneity during stratification increase the number of functional groups?

\section{Material and Methods}

\subsection{Study area}

The typology of the lake system of the Rio Doce middle section (Minas Gerais state, Brazil) includes rare and deep dendritic lakes with slow circulation (e.g. Lake Dom Helvécio), and shallow circular 


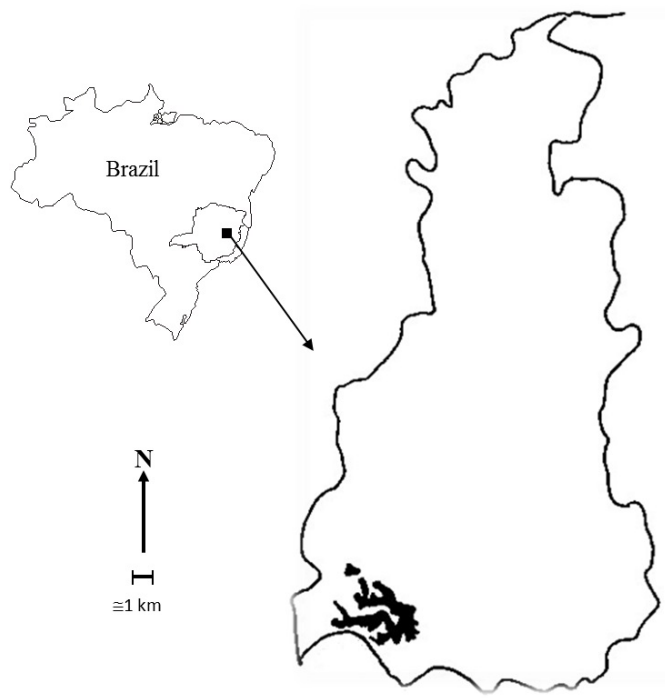

Figure 1. Carioca and Dom Helvécio lakes, southeast Brazil.

lakes with more effective circulation, which are most common in this landscape (e.g. Lake Carioca) (De Meis \& Tundisi, 1997). Two lakes of the Rio Doce middle section were sampled (Figure 1): lake Carioca, which is small, mesotrophic and shallow (maximum depth of $11.8 \mathrm{~m}$ ) and lake Dom Helvécio, which is oligotrophic, dendritic and deep (maximum depth of $39.2 \mathrm{~m}$ ) (Bezerra-Neto \& Pinto-Coelho, 2008).

\subsection{Sampling and analyses}

Sampling was carried out monthly from January 2002 to December 2006. Water samples at different layers (subsurface, $10 \%$ incident light, $1 \%$ incident light and the aphotic zone) of the limnetic zone of both lakes were collected using van Dorn bottles.

Thermocline depth and thermal stability were used for characterizing the thermal structure. Water temperature, dissolved oxygen, electric conductivity, and $\mathrm{pH}$ were monthly measured 'in situ', using a multiparameter probe (Horiba sensor model $U$ 22), at $0.50 \mathrm{~m}$ intervals from the surface to the bottom of the lakes. Water transparency was estimated using a Secchi disk (Cole, 1994). The euphotic zone $\left(Z_{\mathrm{eu}}\right)$ was calculated as 2.7 times the Secchi disk depth (Cole, 1994).

Vertical strata (epilimnion, metalimnion and hypolimnion) were defined according to the temperature profile (Reynolds, 1984), and considering density gradients greater than $0.02 \mathrm{~kg} \mathrm{~m}^{-3} \mathrm{~m}^{-1}$, from water density tables (Hutchinson, 1957). The euphotic zone $\left(Z_{\mathrm{eu}}\right)$ : mixing zone $\left(\mathrm{Z}_{\text {mix }}\right)$ ratio was used as an index for light availability in the mixing zone (Jensen et al., 1994). Thermal stability $\left(\mathrm{g}-\mathrm{cm} \mathrm{cm}^{-2}\right)$ was calculated according to Idso (1973).

Total phosphorus (TP), soluble reactive phosphorus (SRP), total nitrogen $(\mathrm{TN}=$ particulate $\mathrm{N}$ and total dissolved $\mathrm{N}$ ) and dissolved inorganic nitrogen $\left(\mathrm{NO}_{3}^{-}, \mathrm{NO}_{2}^{-}\right.$and $\mathrm{NH}_{4}^{+}$nitrogen) were measured according to Golterman et al. (1978). The Carlson's index adapted by Toledo Junior et al. (1983) for tropical regions was used for characterization of the trophic state.

Phytoplankton quantification was performed according to Utermöhl (1958) and sedimentation time was calculated according to Lund et al. (1958). The sedimentation time was $4 \mathrm{~h}$ for each centimeter of the chamber height. Counting was carried out under a Zeiss inverted microscope at $400 \times$ magnification, considering a minimum of 400 individuals of the most frequent species (Lund et al., 1958). The biovolume $\left(\mu \mathrm{m}^{3} \mathrm{ml}^{-1} \rightarrow \mathrm{mm}^{3} \mathrm{~L}^{-1}\right)$ of each species was estimated from the geometric solid shape that best represented the cell, taken either isolated or combined (Sun \& Liu, 2003; Hillebrand et al., 1999). Biovolume was expressed in dry weight units, where $1 \mathrm{~mm}^{3} \mathrm{~L}^{-1}=1 \mathrm{mg} \mathrm{L}^{-1}$ (Wetzel \& Likens, 2000). Species were classified into functional groups according to Reynolds et al. (2002) and Padisák et al. (2009).

\subsection{Statistical data}

Vertical heterogeneity was estimated according to vertical zonation (epilimnion, metalimnion, and hypolimnion). Biotic and abiotic variables were compared with the Kruskal-Wallis test (Statsoft Inc. v. 4.2).

Multivariate analyses were performed considering a single monthly value of $Z_{\text {mix }}$, Secchi disk (as an indicator of water transparency) and light attenuation coefficient. Phytoplankton biomass and dissolved and total nutrients of the epilimnion, metalimnion, and hypolimnion were measured and integrated arithmetically. A Principal Component Analysis (PCA) of the environmental variables of the five-year series was performed from the covariance matrices, using the abiotic data transformed by $\log (x+1)$.

A multivariate descriptive analysis of the five year abiotic and biotic variables was performed with canonical correspondence analysis (CCA). The significance of environmental variables $(p<0.05)$ was tested using the Monte Carlo's test with 999 unrestricted permutations. The Pearson correlation coefficient $(r)$ resulting from the 
relationship between the ordination values was used, as well as the individual variables for the ordination (McCune \& Mefford, 1997). The functional groups data was transformed by ranging. FITOPAC (Shepherd, 1996) was used for data transformation, whereas PC-ORD v. 3.0 for Windows (McCune \& Mefford, 1997) was employed for all data analyses.

\section{Results}

\subsection{Thermal stability}

The stratification period was characterized by high physical stability values (maximum $408 \mathrm{~g} \mathrm{~cm} \mathrm{~cm}^{-2}$ and $98 \mathrm{~g} \mathrm{~cm} \mathrm{~cm}^{-2}$ at lakes Dom Helvécio and Carioca, respectively) related to a high heterogeneity enhanced by the temperature distribution (Figure 2). The epilimnion layer $\left(Z_{\text {mix }}\right)$ was about $6.5 \mathrm{~m}$ at Lake Carioca and $12 \mathrm{~m}$ at Dom Helvécio. At Lake Carioca, maximum metalimnion and hypolimnion depths were $8.5 \mathrm{~m}$ and $2-3 \mathrm{~m}$, respectively. The beginning of the metalimnion at Lake Dom Helvécio was between 13 and $16 \mathrm{~m}$, and its maximum extension reached $26 \mathrm{~m}$. The mixing zone $\left(\mathrm{Z}_{\text {mix }}\right)$ progressively increased during the turnover period (May-September), mainly in Lake Carioca $\left(Z_{\text {mix }}=Z_{\text {max }}\right)$.

Long periods of thermal stratification (an average of 200 days per year) resulted in the establishment of chemical and nutrient stratification, with nutrient accumulation associated with anoxia at the bottom of both lakes. Despite the total phosphorus (TP) low concentrations, both lakes were classified as mesotrophic (Carioca) and oligotrophic (Dom
Helvecio) and (Table 1 and Table 2). The total phosphorus $(\mathrm{p}=0.000)$ and electrical conductivity $(p=0.000)$ were the only factors that differed between the lakes, with higher values in Lake Carioca (Table 1).

Regarding the vertical profile of light, two distinct phases associated with thermal stability were observed: one of high light availability $(Z e u / Z m i x \geq 1)$ in September-April and another of low availability in May-August (Zeu/Zmix $\leq 1)$.

Principal Component Analysis showed that the first two axes accounted for $66 \%$ of total data variability (Figure 3). Four variables contributed to the Axis 1: mixing zone (ZMIX; $r=0.6$ ); thermal stability $(S ; r=0.6)$; transparency $(S D ; r=0.4)$; and the coefficient of light attenuation $(\mathrm{K} 0 ; \mathrm{r}=-0.4)$. In the case of Axis 2, thermal stability $(S ; r=0.55)$, $\mathrm{P}_{-} \mathrm{PO}_{4}^{-3}(\mathrm{r}=0.12)$, mixing zone (ZMIX; $\left.\mathrm{r}=-0.8\right)$ and the coefficient of light attenuation $(\mathrm{K} 0 ; \mathrm{r}=-0.15)$ showed the highest contribution.

Samples from Dom Helvécio were positively associated with Axis 1 and evidenced differences between thermal stratification and mixing periods, whereas samples from Lake Carioca were associated with the coefficient of light attenuation and $\mathrm{P}_{-} \mathrm{PO}_{4}^{-3}$, and showed no differences between those periods.

\subsection{Phytoplankton functional groups}

Seven functional groups were identified at Lake Carioca and 12 at Lake Dom Helvécio, which corresponded to $c$. $80 \%$ of the total biovolume (Table 3). In Lake Carioca, total biomass ranged

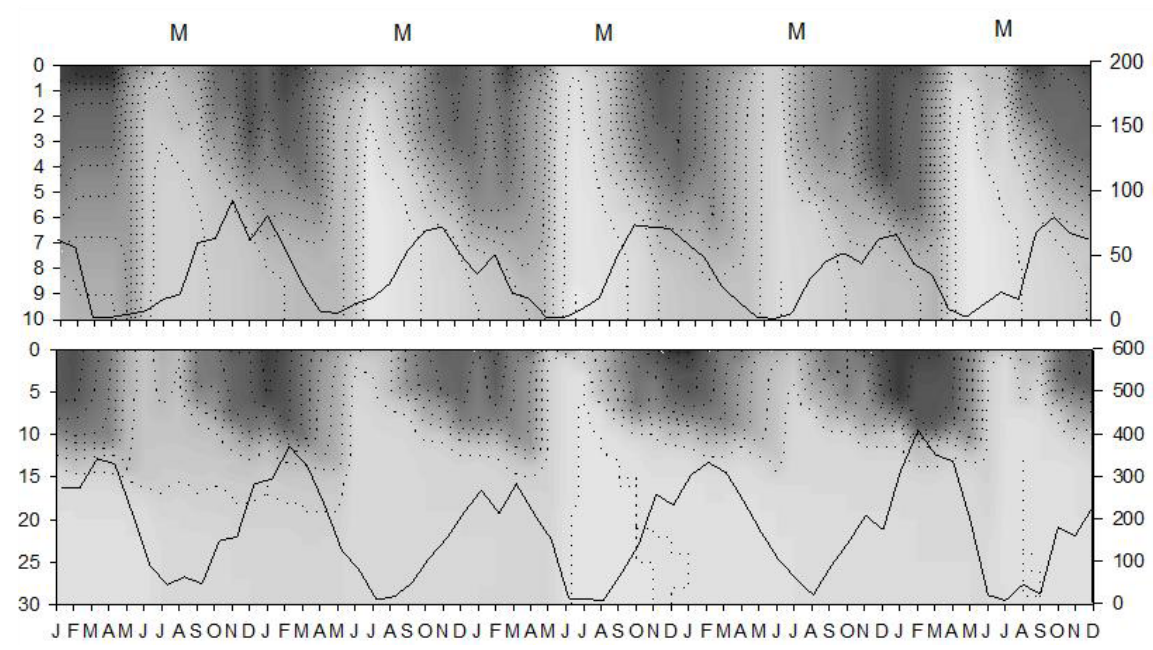

Figure 2. Depth-time diagram of water temperature $\left({ }^{\circ} \mathrm{C}\right)$ and thermal stability (filled line; $\mathrm{g} \mathrm{cm} \mathrm{cm}^{-2}$ ) over 5 years (2002-2006) in lakes Carioca (above) and Dom Helvécio (below), Rio Doce State Park, southeast Brazil (M: mixing period). 
Table 1. Water physical and chemical variables (averages and standard deviations of the five years of Lake Carioca, Rio Doce State Park, Minas Gerais State, southeast Brazil.

\begin{tabular}{|c|c|c|c|c|c|}
\hline Carioca & $\begin{array}{c}\text { Stratification } \\
\text { Period }\end{array}$ & & & $\begin{array}{l}\text { Mixing } \\
\text { Period }\end{array}$ & \\
\hline Transparency (m) & $1.6( \pm 0.4)$ & & & $1.2( \pm 0.3)$ & \\
\hline Light attenuation vertical coefficient $(\mathrm{k})$ & $1.2( \pm 0.3)$ & & & $1.5( \pm 0.5)$ & \\
\hline Zmix & $4( \pm 1.8)$ & & & $10( \pm 1.9)$ & \\
\hline Zeu/Zmix & $1.5( \pm 0.9)$ & & & $0.5( \pm 0.4)$ & \\
\hline \multirow[t]{2}{*}{ Trophic state } & Mesotrophic & & & Mesotrophic & \\
\hline & Epiliminion & Metalimnion & Hypolimnion & Sub-surface & Bottom \\
\hline $\mathrm{pH}$ & $6.07( \pm 0.8)$ & $6.11( \pm 0.8)$ & $6.7( \pm 1.1)$ & $6.1( \pm 1.5)$ & $5.9( \pm 0.8)$ \\
\hline Electrical Conductivity $\left(\mu \mathrm{S} \mathrm{cm}-{ }^{-1}\right)$ & $29.6( \pm 3.7)$ & $47.3( \pm 30.6)$ & $104.8( \pm 34.8)$ & $32.9( \pm 2.9)$ & $51.2( \pm 28)$ \\
\hline Dissolved Oxygen $\left(\mathrm{mg} \mathrm{L}^{-1}\right)$ & $9.3(2.7)$ & $6.4( \pm 3)$ & $4.1( \pm 2.7)$ & $10.5( \pm 4.2)$ & $5.7( \pm 3.4)$ \\
\hline Temperature $\left({ }^{\circ} \mathrm{C}\right)$ & $30.3( \pm 1.7)$ & $26.3( \pm 1.8)$ & $23.8( \pm 1.6)$ & $25.2( \pm 1.9)$ & $22.8( \pm 1.4)$ \\
\hline Total Dissolved Solids (TDS) $\left(\mathrm{mg} \mathrm{L}^{-1}\right)$ & $20.3( \pm 1.7)$ & $32.6( \pm 20.5)$ & $64.1( \pm 24.9)$ & $20( \pm 0)$ & $29.6( \pm 19.5)$ \\
\hline Total Phosphorus $\left(\mu \mathrm{g} \mathrm{L}^{-1}\right)$ & $20.5( \pm 12.6)$ & $33.4( \pm 15.8)$ & $54.2( \pm 132)$ & $24.7( \pm 17.9)$ & $36.6( \pm 32)$ \\
\hline $\mathrm{P}-\mathrm{PO}_{4}{ }^{-3}\left(\mu \mathrm{g} \mathrm{L}^{-1}\right)$ & $3.2( \pm 2.1)$ & $5.7( \pm 4.8)$ & $8( \pm 8.6)$ & $4.0( \pm 3.3)$ & $3( \pm 2.5)$ \\
\hline Total Nitrogen $(\mu \mathrm{g} \mathrm{L}-1)$ & $302.5( \pm 150)$ & $593.6( \pm 435.3)$ & $1159( \pm 734.5)$ & $411( \pm 242)$ & $650.7( \pm 397)$ \\
\hline $\mathrm{N}-\mathrm{NH}_{4}(\mu \mathrm{g} \mathrm{L}-1)$ & $15.2( \pm 10.5)$ & $206.2( \pm 349)$ & $766.8( \pm 593)$ & $65.4( \pm 49.9)$ & $232.3( \pm 240)$ \\
\hline $\mathrm{N}-\mathrm{NO}_{3}(\mu \mathrm{g} \mathrm{L}-1)$ & $6.5( \pm 7)$ & $7.1( \pm 5)$ & $8.5( \pm 6)$ & $13.1( \pm 11.6)$ & $11.7( \pm 9.1)$ \\
\hline $\mathrm{N}-\mathrm{NO}_{2}\left(\mu \mathrm{g} \mathrm{L}^{-1}\right)$ & $1.6( \pm 1.1)$ & $3.3( \pm 4.3)$ & $6.2( \pm 5.8)$ & $2.2( \pm 1.6)$ & $2.5( \pm 1.6)$ \\
\hline
\end{tabular}

Table 2. Water physical and chemical variables (averages and standard deviations of the five years of Lake Dom Helvécio, Rio Doce State Park, Minas Gerais State, southeast Brazil.

\begin{tabular}{|c|c|c|c|c|c|}
\hline Dom Helvécio & $\begin{array}{c}\text { Stratification } \\
\text { Period }\end{array}$ & & & $\begin{array}{l}\text { Mixing } \\
\text { Period }\end{array}$ & \\
\hline Transparency (m) & $3.6( \pm 0.8)$ & & & $2.5( \pm 0.5)$ & \\
\hline Light attenuation vertical coefficient $(k)$ & $0.58( \pm 0.5)$ & & & $0.78( \pm 1.1)$ & \\
\hline Zmix & $12.0( \pm 0.7)$ & & & $32.0( \pm 0.3)$ & \\
\hline Zeu/Zmix & $1.5( \pm 0.5)$ & & & $0.7( \pm 1.7)$ & \\
\hline \multirow[t]{2}{*}{ Trophic state } & Oligotrophic & & & Mesotrophic & \\
\hline & Epiliminion & Metalimnion & Hypolimnion & Sub-surface & Bottom \\
\hline $\mathrm{pH}$ & $6.2( \pm 1.3)$ & $6.0( \pm 1.2)$ & $6.4( \pm 1.5)$ & $6.3( \pm 1.1)$ & $6.3( \pm 1.15)$ \\
\hline Electrical Conductivity $\left(\mu \mathrm{S} \mathrm{cm}^{-1}\right)$ & $38.4( \pm 8.7)$ & $41.6( \pm 13.8)$ & $72.5( \pm 19.3)$ & $44( \pm 5.7)$ & $65.9( \pm 22.5)$ \\
\hline Dissolved Oxygen (mg L-1) & $9.2( \pm 2.8)$ & $6.4( \pm 3.2)$ & $4.1( \pm 3)$ & $10( \pm 4.3)$ & $4.2( \pm 3.3)$ \\
\hline Temperature $\left({ }^{\circ} \mathrm{C}\right)$ & $29.8( \pm 1.3)$ & $26.5( \pm 1.8)$ & $23.8( \pm 0.4)$ & $25.9( \pm 1.35)$ & $23.7( \pm 0.7)$ \\
\hline Total Dissolved Solids ( $\mathrm{mg} \mathrm{L}^{-1}$ ) & $23.2( \pm 6.8)$ & $25.7( \pm 10)$ & $46.3( \pm 12.8)$ & $28.8( \pm 5.3)$ & $40.8( \pm 15.8)$ \\
\hline Total Phosphorus ( $\left.\mu \mathrm{g} \mathrm{L.}{ }^{1}\right)$ & $14.6( \pm 9.3)$ & $27.8( \pm 32.7)$ & $28.7( \pm 35.7)$ & $26.5( \pm 23)$ & $34.2(34.4)$ \\
\hline $\mathrm{P}^{-\mathrm{PO}_{4}}{ }^{-3}(\mu \mathrm{g} \mathrm{L}-1)$ & $3.2( \pm 2.8)$ & $3.7( \pm 2.7)$ & $4.9( \pm 3.3)$ & $3.4( \pm 3.9)$ & $4.2( \pm 3.9)$ \\
\hline Total Nitrogen $\left(\mu \mathrm{g} \mathrm{L}^{-1}\right)$ & $337.8( \pm 163.8)$ & $448.3( \pm 248)$ & $807.4( \pm 456)$ & $447.6( \pm 167)$ & $805.7(333.1)$ \\
\hline $\mathrm{N}-\mathrm{NH}_{4}\left(\mu \mathrm{g} \mathrm{L}^{-1}\right)$ & $47.5( \pm 63)$ & $102.3( \pm 153.2)$ & $489.5( \pm 428.1)$ & $136.1( \pm 125.2)$ & $409.1( \pm 326.8)$ \\
\hline N-NO3 $\left(\mu g \mathrm{~L}^{-1}\right)$ & $9.4( \pm 8.2)$ & $7.7( \pm 5.7)$ & $10.6( \pm 10)$ & $9.9( \pm 7)$ & $7.97( \pm 5.9)$ \\
\hline N-NO2 $\left(\mu \mathrm{g} \mathrm{L}^{-1}\right)$ & $1.7( \pm 1.4)$ & $2.2( \pm 2.1)$ & $2.6( \pm 2.8)$ & $1.6( \pm 0.9)$ & $3.1( \pm 2.96)$ \\
\hline
\end{tabular}

from 0.0003 to $47.2 \mathrm{mg} \mathrm{L}^{-1}$, and the maximum values $\left(>10 \mathrm{mg} \mathrm{L}^{-1}\right)$ were found at the metalimnion during the stratification period. In Lake Dom Helvécio, the biomass ranged from 0.1 to $19 \mathrm{mg} \mathrm{L}^{-1}$, and the maximum values were identified between the epi and metalimnion.

\subsection{Lake carioca}

In the epilimnion, group $\mathbf{N}_{\mathbf{A}}$ accounted for $15-30 \%$ of the total biomass. Larger specimens $(>20 \mu \mathrm{m})$, as well as the most morphologically complex ones (e.g. Staurastrum rotula), were more abundant in the hypolimnion (Table 3). Colonial 


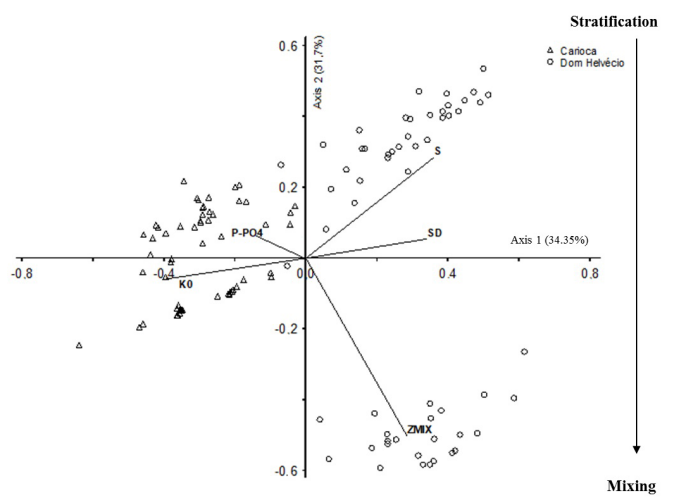

Figure 3. PCA biplots of water physical and chemical variables from lakes Carioca and Dom Helvécio (southeast Brazil), over the study period (2000-2006). green algae (group F) and small green algae (group X1) exhibited a remarkable contribution between epi and metalimnion. Dinoflagellates (group $\mathbf{L}_{\mathbf{o}}$ ) also constituted a typical epilimnetic assemblage. The group $\mathbf{R}$ had populations with maximum biomass $\left(30.5 \mathrm{mg} \mathrm{L}^{-1}\right)$ at the metalimnion and hypolimnion. During the mixing period, group $\mathbf{S}_{1}$ showed the largest biomass contribution.

\subsection{Lake Dom Helvécio}

In the epilimnion, maximum values of desmid biomass (13.2 $\mathrm{mg} \mathrm{L}^{-1}$ ) were recorded in 2002. In the metalimnion and hypolimnion, only S. rotula contributed substantially to total biomass. In addition, in the epi-metalimnion interface,

Table 3. Phytoplankton functional groups for Carioca and Dom Helvécio lakes between 2002-2006.

\begin{tabular}{|c|c|c|c|}
\hline Period & Layer & Species & $\begin{array}{c}\text { Functional } \\
\text { Group }\end{array}$ \\
\hline \multicolumn{4}{|c|}{ Carioca } \\
\hline \multirow[t]{7}{*}{ Stratification } & Epilimnion & $\begin{array}{l}\text { Cosmarium asphaerosporum Nordst. var. strigosum Nordst.; S. tetracerum } \\
\text { (Kütz.) Ralfs ex Ralfs var. tetracerum f. tetracerum; Staurodesmus crassus } \\
\text { (West) Flor; Teilingia granulata (Roy \& Biss.) Bourr. }\end{array}$ & $\mathbf{N}_{\mathrm{A}}$ \\
\hline & & Gymnodinium sp.; Peridinium volzii Lemmermann & $\mathrm{L}_{\mathrm{o}}$ \\
\hline & & Chlorella vulgaris Beyerinck & $x_{1}$ \\
\hline & Metalimnion & Botryococcus braunii Kützing; Coelastrum sphaericum Nägeli & $\mathbf{F}$ \\
\hline & & Pseudanabaena galeata Böcher & $\mathbf{R}$ \\
\hline & Hypolimnion & $\begin{array}{l}\text { Planktolyngbya limnetica (Lemmermann) Komárková-Legnerová \& } \\
\text { Cronberg; Pseudanabaena galeata Böcher; Pseudanabaenaceae NI }\end{array}$ & $\mathbf{R}$ \\
\hline & & Staurastrum rotula Nordstedt & $\mathbf{P}$ \\
\hline $\begin{array}{l}\text { Mixing Period } \\
\left(Z_{\text {mix }}=Z_{\max }\right)\end{array}$ & & Lyngbya sp. & $\mathbf{S}_{1}$ \\
\hline \multicolumn{4}{|c|}{ Dom Helvécio } \\
\hline \multirow[t]{9}{*}{ Stratification } & Epilimnion & $\begin{array}{l}\text { Cosmarium asphaerosporum Nordst. var. strigosum Nordst.; C. contractum } \\
\text { O.Kirchner; Staurastrum laeve Ralfs, S. tetracerum (Kütz.) Ralfs ex Ralfs } \\
\text { var. tetracerum f. tetracerum; S. taylorii Grönblad; S. smithii; Staurodesmus } \\
\text { crassus (West) Flor; Teilingia granulata (Roy \& Biss.) Bourr. }\end{array}$ & $\mathbf{N}_{\mathrm{A}}$ \\
\hline & & Chlorella vulgaris Beyerinck & $\mathbf{x}_{1}$ \\
\hline & & Closterium aciculare T.West & $\mathbf{P}$ \\
\hline & & $\begin{array}{l}\text { Planktolyngbya limnetica (Lemmermann) Komárková-Legnerová \& } \\
\text { Cronberg; Pseudanabaena galeata Böcher }\end{array}$ & $\mathbf{R}$ \\
\hline & & Urosolenia longiseta (O.Zacharias) Edlund \& Stoermer & A \\
\hline & Metalimnion & $\begin{array}{l}\text { Planktolyngbya limnetica (Lemmermann) Komárková-Legnerová \& } \\
\text { Cronberg; Pseudanabaena galeata Böcher }\end{array}$ & $\mathbf{R}$ \\
\hline & & Cylindrospermopsis raciborskii (Woloszynska) Seenayya \& Subba Raju & $\mathbf{S}_{\mathrm{N}}$ \\
\hline & Hypolimnion & Staurastrum rotula Nordstedt & $\mathbf{P}$ \\
\hline & & $\begin{array}{l}\text { Limnothrix sp.; Oscillatoria limosa C.Agardh ex Gomont, Planktolyngbya } \\
\text { limnetica (Lemmermann) Komárková-Legnerová \& Cronberg; } \\
\text { Pseudanabaena galeata Böcher }\end{array}$ & $\mathbf{R}$ \\
\hline \multirow{4}{*}{$\begin{array}{l}\text { Mixing Period } \\
\left(Z_{\text {mix }}=Z_{\max }\right)\end{array}$} & & Cryptomonas brasiliensis A. Castro & $\mathbf{Y}$ \\
\hline & & & \\
\hline & & Lyngbya sp. & $\mathbf{S}_{1}$ \\
\hline & & Peridinium inconspicuum Lemmermann; P. volzii Lemmermann & $\mathrm{L}_{\mathrm{o}}$ \\
\hline
\end{tabular}


group $\mathbf{A}$ and bloom-forming cyanobacteria $\left(\mathbf{S}_{\mathrm{N}}\right)$ were registered. Other groups, such as group $\mathbf{Y}$ represented by Cryptomonas brasiliensis, exhibited the highest biomass in the epilimnion during the stratification period and in the aphotic zone during mixing.

The group $\mathbf{R}$ was detected during stratification in the epilimnion-metalimnion as well as in the hypolimnion, with a high biomass of Planktolyngbya limnetica, Limnothrix sp., Pseudanabaena galeata and Oscilatoria limosa (maximum of $3 \mathrm{mg} \mathrm{L}^{-1}$ ). During the mixing period, their contributions were above 50\%, with Limnothrix sp. being replaced by Lyngbya sp. and group $\mathbf{S 1}$.

\subsection{Canonical analyses}

CCA resulted in eigenvalues of 0.50 e 0.073 for axes 1 and 2, respectively. Pearson correlation for axes $1(0.88)$ and $2(0.67)$ indicated a relationship between abiotic factors and functional groups at a monthly scale. Monte Carlo's test showed that the first two canonic axes were statistically significant $(\mathrm{p}<0.01$; Figure 4).

According to the canonic coefficients, the thermal stability $(S ; \mathrm{r}=0.88)$, mixing zone (ZMIX; $r=0.84)$ and coefficient of vertical light attenuation $(\mathrm{K} 0 ; \mathrm{r}=-0.20)$ were associated with

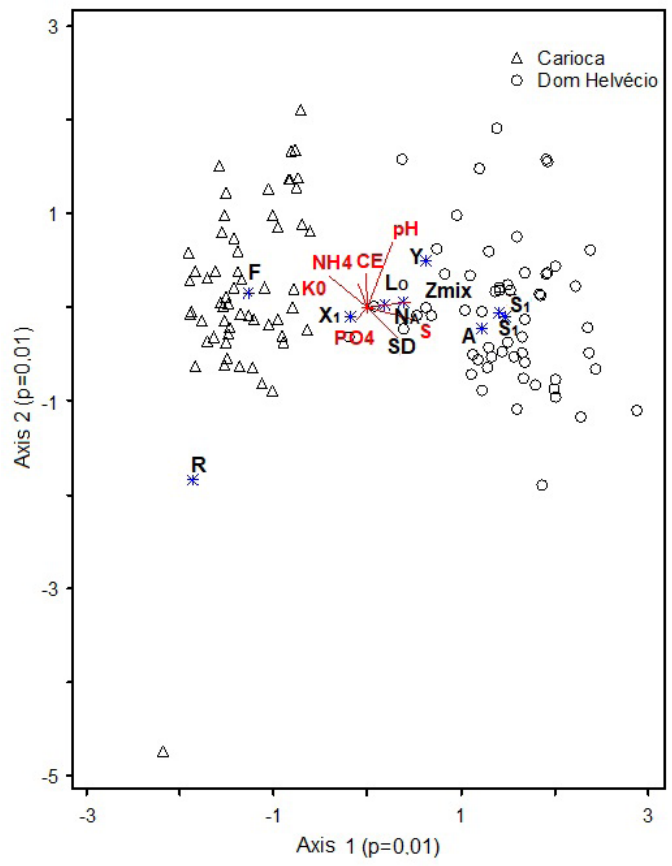

Figure 4. CCA ordination diagram of the sampling units in relation to the functional groups $\left(\mathrm{mg} \mathrm{L}^{-1}\right)$ at lakes Dom Helvécio and Carioca and main abiotic variables during the period 2002-2006.
Axis 1. Intra-set correlations confirmed thermal stability $(r=0.70)$, mixing zone $(r=0.67)$, and the coefficient of vertical light attenuation $(r=-0.58)$ as determining variables for Axis 1 . Axis 2 presented higher canonic coefficients for $\mathrm{pH}(\mathrm{r}=0.89)$, electrical conductivity (EC; $r=0.25$ ), coefficient vertical light attenuation $(\mathrm{K} 0 ; \mathrm{r}=0.21), \mathrm{N}^{-N_{4}}$ $(\mathrm{r}=0.15), \mathrm{P}_{-} \mathrm{PO}_{4}(\mathrm{r}=-0.19)$ and transparency (DS; $r=-0.28)$ than Axis 1. Intra-set correlations indicated $\mathrm{pH}(\mathrm{r}=0.72)$, electrical conductivity $(\mathrm{r}=0.38)$, coefficient of vertical light attenuation $(r=0.35), N_{-N H}(r=0.26), \mathrm{P}_{4} \mathrm{PO}_{4}(r=-0.14)$ and transparency $(\mathrm{r}=-0.35)$ as the ordination determining factors.

Along Axis 1, the coefficient of vertical light attenuation $(\mathrm{r}=-0.20)$, and the highest concentrations of nutrients $\left(\mathrm{N}-\mathrm{NH}_{4}\right.$ and $\left.\mathrm{P}_{-} \mathrm{PO}_{4}\right)$ were associated with the most representative functional groups of Lake Carioca, especially groups $\mathbf{X}_{1}(\mathrm{r}=-0.2), \mathbf{F}(\mathrm{r}=-1.26), \mathbf{S}_{1}(\mathrm{r}=-1.27)$ and $\mathbf{R}(\mathrm{r}=-1.86)$. Along this axis, functional groups $S_{1}(r=1.5), S_{N}(r=1.4), A(r=1.22), Y(r=0.65)$, $\mathbf{N}_{\mathbf{A}}(\mathrm{r}=0.40)$ and $\mathbf{L}_{\mathbf{O}}(\mathrm{r}=0.18)$ were associated with the mixing zone (ZMIX; $r=0.67$ ) and the transparency (SD; r = -0.28) in Lake Dom Helvécio.

\section{Discussion}

The vertical distribution of functional groups appears to be controlled by a set of factors, such as thermal stability, nutrient limitations, underwater light conditions and phytoplankton characteristics (buoyance capacity) (e.g. Reynolds, 1984). These factors are highly influenced by the compartmentalization resulting from thermal stability during the stratification period.

The drastic decrease in the biomass of functional groups during the mixing period in both lakes $(\geq 80 \%)$ was an indicative of the seasonal break of thermal stability. Some models of phytoplankton vertical distribution include stratification, spatially varying mixing conditions and limitation of different resources within the mixed layer. Multiple nutrients sources can create multi-modal phytoplankton distributions (Mellard et al., 2011). Our results showed that the vertical distribution of phytoplankton was influenced by light conditions and nutrient availability during stratification. The biomass of cyanobacteria increased at the deepest layers while of desmids increased at the upper layers of lakes (meta e hypolimnion), which was related to a lower concentration of nutrients and a higher light availability in $\mathrm{Z}_{\text {mix }}$ during stratification, as previously reported for other 
lakes (Moreti et al., 2013). Mellard et al. (2011) suggested that phytoplankton biomass might sustain source populations in both mixed and deep layers simultaneously, with favorable conditions and resource availability for growth at both depths, which represents a bimodal distribution.

Thermal stability and partial atelomixis synergistically supported the presence of groups $\mathbf{N}_{\mathbf{A}}$ and $\mathbf{A}$, and of unicellular Chlorococcales (group $\mathbf{X}_{\mathbf{1}}$ ) in the epilimnion, while of cenobial coccoid Chlorococcales (group F) in the metalimnion. Previous studies have reported that the increase in desmid biomass in tropical lakes is related to the epilimnetic mixing resulting from diurnal variations in the air temperature (Barbosa $\&$ Pádisak 2002; Tavera \& Martínez-Almeida, 2005; Souza et al., 2008). Therefore, the mixing regime (turbulence) and the physical variables (Zeu:Zmix) are the most important factors for the maintenance and growth of those functional groups within the epilimnion, especially of non-motile species with a sinking tendency.

The persistence of cyanobacteria may be directly associated with the existence of a thermal stratification in the water column (Maier et al., 2001). The ability of members of this group to take advantage of intensified and prolonged periods of thermal stratification is well-known (Huisman et al., 2005). We found that thermal stability increased the cyanobacteria biomass in the metalimnion and in the hypolimnion of both lakes (Reynolds et al., 1983; Barbosa \& Padisák, 2002; Padisák et al., 2003), evidencing an inter-annual recurrent pattern since the 1980s (Reynolds et al., 1983).

At the thermocline depth, cyanobacteria find the appropriate conditions for growth, such as suitable light levels, high stability, and nutrients from the hypolimnion that frequently entrained into the epilimnion (Moreno-Ostos et al., 2006). However, the biomass of group $\mathrm{R}$ was higher in Lake Carioca than Dom Helvécio, probably due to the interaction between the high trophic state, physical factors and low transparency associated with an increase in the concentration of pigmented organic substances (Bezerra-Neto et al., 2006).

Singularities related to high water temperature and the relative hydrological isolation found in the two lakes of the middle section of the Rio Doce system indicate the almost absence of physical disturbances (Reynolds, 1997). Some conditions, such as the strength of gradients (e.g. resulting from the relative density of the different layers) and the depth of light penetration, may represent effective mechanisms of niche segregation (Naselli-Flores et al., 2003).

In the studied lakes, such small-scale disturbances occurred due to breakage of superficial secondary thermoclines by allochthonous factors of disturbance (e.g. wind and rain), resulting in partial atelomixis (Barbosa \& Padisák, 2002). The seasonal disruption of stability may contribute to reducing the number of habitats and consequently the availability of niches that are suitable for colonization. The decrease in habitat heterogeneity by disruption of thermal stability also modifies the resource availability (light and nutrients), intensifying some processes such as competitive exclusion.

Seasonal climatic changes induced shifts in the thermal structure of lakes, which caused the loss of the stability in the water column. Consequently, changes in the phytoplankton composition of the lakes promoted the collapse of populations during the stratified period, and cyanobacteria (group S1) dominated during the mixing. Despite adaptations to stratification, cyanobacteria are known to dominate or co-dominate during mixing (Soares et al., 2013), probably due to their ability to tolerate shading and to succeed in turbid and eutrophic lakes, which are typical conditions of lakes during mixing (Padisak et al., 2009).

In conclusion, thermal stability was the main factor generating vertical heterogeneity during the stratification, favoring the coexistence of FGs. In addition, the highest biomass of FGs supported by a higher thermal stability, the larger vertical extension of the euphotic zone and of the epi, meta and hypolimnetic layers were found in the deeper and more stable Lake Dom Helvécio. Our results corroborated previous studies in which phytoplankton variations in deep lakes are predictable and less susceptible to stochastic events (Salmaso, 2003).

\section{References}

BARBOSA, F.A.R. and PADISÁK, J. The forgotten lake stratification pattern: atelomixis and its ecological importance. Verhandlungen der Internationalen Vereinigung fur Theoretische und Angewandte Limnologie, 2002, 28, 1385-1395.

BEZERRA-NETO, J.F. and PINTO-COELHO, R.M. Morphometric study of lake Dom Helvécio, Parque Estadual do Rio Doce (PERD), Minas Gerais, Brazil: a reevaluation. Acta Limnologica Brasiliensia, 2008, 20(2), 161-167.

BEZERRA-NETO, J.F., BARBOSA, P.M. and BARBOSA, F.A.R. Temporal variation of attenuation of the visible radiation in four lakes of Parque 
Estadual do Rio Doce (PERD), Minas Gerais, Brazil. Acta Limnologica Brasiliensia, 2006, 18, 39-46.

COLE, G.A. Textbook of limnology. 4th ed. Illinois: Waveland Press, Prospect Heights, 1994.

DE MEIS, M.R.M. and TUNDISI, J.G. Geomorphological and limnological process as a basis for lake tipology: the middle Rio Doce lake system. In J.G. Tundisi and Y. Saijo, eds. Limnological studies in the Rio Doce Valley Lakes. São Carlos: Brazilian Academy of Sciences, 1997, pp. 25-50.

ESTRADA, M. and BERDALET, E. Phytoplankton in a turbulent world. Scientia Marina, 1997, 61(1), 125-140.

GOLTERMAN, H.L., CLYMO, R.S. and OHMSTAD, M.A.M. Methods for chemical analyses of freshwaters. 2nd ed. Oxford \& Edinburg: Blackwell Scientific Publications, 1978.

HILLEBRAND, H., DÜRSELEN, C.D., KIRSCHTEL, D., POLLINGHER, D. and ZOHARY, T. Biovolume calculation for pelagic and benthic microalgae. Journal of Phycology, 1999, 35(2), 403-424. http://dx.doi.org/10.1046/j.15298817.1999.3520403.x.

HUISMAN, J., MATTHIJS, H.C.P. and VISSER, P.M. Harmful cyanobacteria. Netherlands: Springer, 2005. http://dx.doi.org/10.1007/1-4020-3022-3.

HUTCHINSON, G. E. Concluding remarks. Cold Spring Harbor Symposia on Quantitative Biology, 1957, 22: 415-442.

HUTCHINSON, G.E. The paradox of the plankton. American Naturalist, 1961, 95(882), 137-145. http:// dx.doi.org/10.1086/282171.

IDSO, S. On the concept of lake stability. Limnology and Oceanography, 1973, 18(4), 681-683. http://dx.doi. org/10.4319/lo.1973.18.4.0681.

JENSEN, P., JEPPESEN, E., OLRIK, K. and KRISTENSEN, P. Impact of nutrients and physical factors on the shift from Cyanobacterial to Chlorophyte dominance in shallow Danish lakes. Canadian Journal of Fisheries and Aquatic Sciences, 1994, 51(8), 1692-1699. http://dx.doi.org/10.1139/ f94-170.

LEWIS JUNIOR, W.M. The thermal regime of Lake Lanao (Phillipines) and its theoretical implications for tropical lakes. Limnology and Oceanography, 1973, 18(2), 200-217. http://dx.doi.org/10.4319/ lo.1973.18.2.0200.

LOPES, M.R.M., BICUDO, C.E.M. and FERRAGUT, C. Spatial and temporal variation of phytoplankton in a shallow tropical oligotrophic reservoir, southeast Brazil. Hydrobiologia, 2005, 542(1), 235-247. http:// dx.doi.org/10.1007/s10750-004-8332-z.

LUND, J.W.G., KIPLING, C. and LECREN, E.D. The inverted microscope method of estimating algal numbers and the statistical basis of estimations by counting. Hydrobiologia, 1958, 11(2), 143-170. http://dx.doi.org/10.1007/BF00007865.

MACARTHUR, R.H. and MACARTHUR, J.W. On bird species diversity. Ecology, 1961, 42(3), 594-598. http://dx.doi.org/10.2307/1932254.

MAIER, H.R., BURCH, M.D. and BORMANS, M. Flow management strategies to control blooms of the cyanobacterium Anabaena circinalis, in the river Murray at Morgan, South Australia. Regulated Rivers: Research and Management, 2001, 17(6), 637-650. http://dx.doi.org/10.1002/rrr.623.

MARGALEF, R. Life-forms of phytoplankton as survival alternatives in an unstable environment. Oceanologica Acta, 1978, 1(4), 493-509.

MCCUNE, B. and MEFFORD, M.J. PC-ORD. Multivariate analysis of ecological data, Version 3.0. Oregon: MjM Software Design, 1997.

MELLARD, J.P., YOSHIYAMA, K., LITCHMAN, E. and KLAUSMEIER, C.A. The vertical distribution of phytoplankton in stratified water columns. Journal of Theoretical Biology, 2011, 269(1), 1630. http://dx.doi.org/10.1016/j.jtbi.2010.09.041. PMid:20932846.

MORENO-OSTOS, E., CRUZ-PIZARRO, L., BASANTA, A., ESCOT, C. and GEORGE, D.G. Algae in the motion: spatial distribution of phytoplankton in thermally stratified reservoirs. Limnetica, 2006, 25(1-2), 205-217.

MORETI, L.O.R., MARTOS, L., BOVOSCOMPARIN, V.M. and RODRIGUES, L.C. Spatial and temporal fluctuation of phytoplankton functional groups in a tropical reservoir. Acta Scientiarum. Biological Sciences, 2013, 35(3), 359366. http://dx.doi.org/10.4025/actascibiolsci. v35i3.12998.

NASELLI-FLORES, L., PADISÁK, J., DOKULIL, M.T. and CHORUS, I. Equilibrium/steady-state concept in phytoplankton ecology. Hydrobiologia, 2003, 502(1-3), 395-403. http://dx.doi.org/10.1023/ B:HYDR.0000004297.52645.59.

PÁDISAK, J., BARBOSA, F.A.R., KOSHEL, R. and KRIENITZ, L. Deep layer Cyanoprokariota maxima in temperate and tropical lakes. Archiv für Hydrobiologie Special Issues Advances in Limnology, 2003, 58, 175-199.

PADISÁK, J., CROSSETTI, L.O. and NASELLIFLORES, L. Use and misuse in the application of the phytoplankton functional classification: a critical review with updates. Hydrobiologia, 2009, 621(1), 1-19. http://dx.doi.org/10.1007/s10750008-9645-0.

REYNOLDS, C.S. The ecology offreshwater phytoplankton. Cambridge: Cambridge University Press, 1984.

REYNOLDS, C.S. Vegetation processes in the pelagic: a model for ecosystem theory. Oldendorf/Luhe: Ecology Institute, 1997. 
REYNOLDS, C.S., HUSZAR, V., KRUK, C., NASELLI-FLORES, L. and MELO, S. Towards a functional classification of the freshwater phytoplankton. Journal of Plankton Research, 2002, 24(5), 417-428. http://dx.doi.org/10.1093/ plankt/24.5.417.

REYNOLDS, C.S., TUNDISI, J.G. and HINO, K. Observations on a metalimneticLyngbya population in a stably stratified tropical lake (Lagoa Carioca, eastern Brasil). Archiv für Hydrobiologie, 1983, 97, 7-17.

RIGOSI, A. and RUEDA, F. J. Propagation of uncertainty in ecological models of reservoirs: from physical to population dynamic predictions. Ecological Modelling, 2012, 247:199-209. https:// doi.org/10.1016/j.ecolmodel.2012.08.022.

SALMASO, N. Life strategies, dominance patterns and mechanisms promoting species coexistence in phytoplankton communities along complex environmental gradients. Hydrobiologia, 2003, 502(1-3), 13-36. http://dx.doi.org/10.1023/ B:HYDR.0000004267.64870.85.

SALMASO, N., NASELLI-FLORES, L. and PADISÁK, J. Functional classifications and their application in phytoplankton ecology. Freshwater Biology, 2015, 60(4), 603-619. http://dx.doi.org/10.1111/ fwb. 12520 .

SHEPHERD, G.J. FITOPAC1: manual de usuário. Campinas: Universidade Estadual de Campinas, 1996.

SOARES, M.C.S., HUSZAR, V.L., MIRANDA, M.N., MELLO, M.M., ROLAND, F. and LÜRLING, M. Cyanobacterial dominance in Brazil: distribution and environmental preferences. Hydrobiologia, 2013, 717(1), 1-12. http://dx.doi.org/10.1007/s10750013-1562-1.
SOUZA, M.B.G., BARROS, C., BARBOSA, F.A.R., HAJNAL, E. and PADISÁK, J. Role of atelomixis in replacement of phytoplankton assemblages in Dom Helvécio Lake, Southeast Brazil. Hydrobiologia, 2008, 607(1), 211-224. http://dx.doi.org/10.1007/ s10750-008-9392-2.

SUN, J. and LIU, D. Geometric models for calculating cell biovolume and surface area for phytoplankton. Journal of Plankton Research, 2003, 25(11), 1331 1346. http://dx.doi.org/10.1093/plankt/fbg096.

TAVERA, R. and MARTÍNEZ-ALMEIDA, V. Atelomixis as a possible driving force in the phytoplankton composition of Zirahuén, a warmmonomictic tropical lake. Hydrobiologia, 2005, 533(1-3), 199-208. http://dx.doi.org/10.1007/ s10750-004-2418-5.

TOLEDO JUNIOR, A.P., TALARICO, M., CHINEZ, S.J. and AGUDO, E.G. 1983. The application of simple models for evaluating eutrophication processes in tropical lakes and reservoirs. In: Annals of the Brazilian Congress of Sanitary and Environmental Engineering. Rio de Janeiro: ABES, pp. 1-34.

UTERMÖHL, H. Zur Vervolkomnung der quantitative Phytoplankton Methodik. Mitteilungen Internationale Vereinigung Theoretische und Angewandte Limnologie, 1958, 9, 1-38.

WETZEL, R.G. and LIKENS, G.E. Limnological analyses. New York: Springer-Street, 2000. http:// dx.doi.org/10.1007/978-1-4757-3250-4.

ZOHARY, T., PADISÁK, J. and NASELLI-FLORES, L. Phytoplankton in the physical environment: beyond nutrients, at the end, there is some light. Hydrobiologia, 2010, 639(1), 261-269. http://dx.doi. org/10.1007/s10750-009-0032-2.

Received: 30 June 2017 Accepted: 04 June 2018 